Article

\title{
Loss of Liquid Lithium Coolant in an Accident in a DONES Test Cell Facility
}

\author{
Danilo Nicola Dongiovanni ${ }^{1, *}$ and Matteo $\mathrm{D}^{\prime}$ Onorio $^{2}$ (D) \\ 1 ENEA, CR. Frascati, FSN-TEN Department, via Enrico Fermi, 45, 00044 Frascati, Italy \\ 2 Department of Astronautical Electrical and Energy Engineering (DIAEE), Sapienza University of Rome, C.so \\ Vittorio Emanuele II 244, 00186 Rome, Italy; matteo.donorio@uniroma1.it \\ * Correspondence: danilo.dongiovanni@enea.it
}

check for updates

Citation: Dongiovanni, D.N.;

D'Onorio, M. Loss of Liquid Lithium Coolant in an Accident in a DONES Test Cell Facility. Energies 2021, 14, 6569. https://doi.org/10.3390/ en14206569

Academic Editors: Dan Gabriel Cacuci and Marica Eboli

Received: 30 July 2021

Accepted: 4 October 2021

Published: 12 October 2021

Publisher's Note: MDPI stays neutral with regard to jurisdictional claims in published maps and institutional affiliations.

Copyright: (c) 2021 by the authors. Licensee MDPI, Basel, Switzerland. This article is an open access article distributed under the terms and conditions of the Creative Commons Attribution (CC BY) license (https:/ / creativecommons.org/licenses/by/ $4.0 /)$.

\begin{abstract}
A Demo-Oriented early NEutron Source (DONES) facility for material irradiation with nuclear is currently being designed. DONES aims to produce neutrons with fusion-relevant spectrum and fluence by means of $\mathrm{D}-\mathrm{Li}$ stripping reactions occurring between a deuteron beam impacting a stable liquid lithium flowing film implementing the target. Given the hazard constituted by the liquid lithium inventory and the potential risk of reactions with water, air, and concrete eventually resulting in fire events, the Target Test Cell (TTC) is filled with helium and the reinforced concrete walls forming the bio-shield are covered with steel liners. A loss of Li in TTC, due to a large break in the Quench Tank, is postulated, and consequences are deterministically studied. With the TTC liner being water-cooled, the impact of the liner temperature rise following a leakage event is evaluated. Two separate MELCOR code models have been defined for the liquid lithium loop and water-cooled loop and are numerically coupled. The amount of leaked inventory dependent on the implemented safety logic and impact on TTC containment is evaluated. The water pressurization pattern within the liner cooling loop is studied to highlight possible risks of lithium-water/concrete reactions.
\end{abstract}

Keywords: fusion; DONES; liquid lithium; LOCA; Melcor; numeric coupling

\section{Introduction}

Special materials able to withstand outstanding neutronic loads will be required for the exploitation of nuclear fusion energy. However, there is limited experience relating to materials exposed to such load conditions. In particular, in-vessel components will be subject to thermal and neutron loads with energy up to around $14.1 \mathrm{MeV}$ and fluence leading to 5-15 displacements per atom (dpa) [1,2] in the irradiated components (first wall, divertor) able to alter their structural and functional behavior.

The IFMIF-DONES (International Fusion Material Irradiation Facility-DEMO Oriented NEutron Source) facility for material irradiation is currently being designed within the EUROfusion programme [3] to fill this knowledge gap in view of a DEMOnstration fusion power plant expected for the mid-2040s [4]. DONES achieves the production of neutrons with fusion-relevant spectrum and fluence through D-Li stripping reactions occurring between a $125 \mathrm{~mA}$ and $40 \mathrm{MeV}$ deuteron beam impacting a stable liquid lithium flowing film implementing the target.

A safety analyses campaign [5] is ongoing within the DONES project to assess the DONES system ability to handle any abnormal event ensuring safe conditions for workers and the population. To reach the goal, a selection of the analyses has been done using the FMECA plan and FMEAs studies.

As part of the conceptual design, a selection of accident events has been studied deterministically for lithium systems and or the test systems interface either by MELCOR code [6] or RELAP code [7].

The exploitation of liquid lithium within the facility constitutes a hazard with potential risk of reactions with air, water, and concrete, eventually resulting in fire events [8]. 
Therefore, great attention has been paid to the DONES design to avoid any direct contact between reactants (air, water, concrete) such as the use of an inert atmosphere (helium, argon) or double-stage heat removal systems lithium-oil/oil-water. Safety mitigation provisions are also in place to prevent the possible reaction of lithium and the reinforced concrete TC walls forming the bio shield. In particular, all TC is covered by a steel liner layer to prevent liquid lithium-concrete reactions in the case of a loss of liquid lithium in an accident. Despite such provisions, deterministically assessing the consequences of possible accidents is of paramount importance in the early phases of the design to identify safety concerns. Assessments have been performed in the past for other test facilities exploiting liquid lithium $[9,10]$. Therefore, a preliminary analysis on the consequences of postulating fire events in the DONES lithium system has also been performed [11].

In the present analysis, a loss of Li in TTC (LTTC1 Postulated Initiating Event) due to large break in the Quench Tank is postulated and consequences deterministically studied with MELCOR [12-14]. In particular, the amount of leaked inventory and its impact on TTC containment and the atmosphere is evaluated. The TTC liner is cooled by a cooling water loop, and the effect of the temperature rise due to leaked lithium inventory on the liner floor and underlying cooling lines is evaluated. To overcome the MELCOR limitation for two cooling fluids contemporary usage, two different MELCOR models have been defined for the liquid lithium loop and water-cooled loop and are numerically coupled by means of external data exchange for interfacing heat structures. Possible water pressurization within the cooling loop has been studied.

\section{Materials and Methods}

\subsection{System Description}

The DONES facility is composed of three main systems (Figure 1) and several auxiliary systems [3]. The accelerator system is in charge of accelerating and focusing deuteron ions into a beam with a $125 \mathrm{~mA}$ current and $40 \mathrm{MeV}$ energy. The beam flies within a vacuum conduit entering the Test Cell within a beam duct until a vacuum chamber (Figure 2) where it impacts the lithium film to have D-Li striping reactions and produces fusion-spectra neutrons [15]. A backplate (BP) is placed between the lithium film and the High Flux Testing Module [16]. The lithium system [17] main lithium loop provides liquid lithium flowing film for striping reactions. The lithium main loop is composed of the Target Assembly (TA) [18] located in the TC, which in turn is composed of pipework leading the lithium to the vacuum chamber area where the thin liquid lithium film is created by means of a flow straighter and reducing nozzle (ST-NZ). Below the target area where the beam impacts the lithium film, lithium is collected in a quench tank (QT) before exiting the TC towards the lithium system room. In order to obtain liquid lithium film, specific velocity/mass flow rate and thermodynamic conditions need to be maintained in the loop. This task is in charge of the part of the lithium main loop located in the lithium room. In particular, lithium flow is provided by an Electromagnetic Pump (EMP) and is measured by an EM flow meter. A Dump Tank (DT) collecting lithium at shutdown is also located therein. The Lithium System (LS) includes three main systems; a Heat Removal System (HRS) is deployed in two rooms housing the main Li loop. Beam heat deposited on the lithium film is exhausted within a primary Heat Exchanger (HX) exploiting a secondary oil loop to prevent lithium-water reactions and is located in the lithium main room. In turn, heat transferred to the oil secondary loop is transferred to a tertiary water loop located in a separate room, considered out of scope. The TC Atmosphere [19] is He at a pressure of $20 \mathrm{kPa}$, with a free volume of $47.1 \mathrm{~m}^{3}$. The Lithium System (LS) [17] is Ar buffered during normal operation and is slightly depressurized $(-140 \mathrm{~Pa})$ with respect to standard atmospheric pressure. 


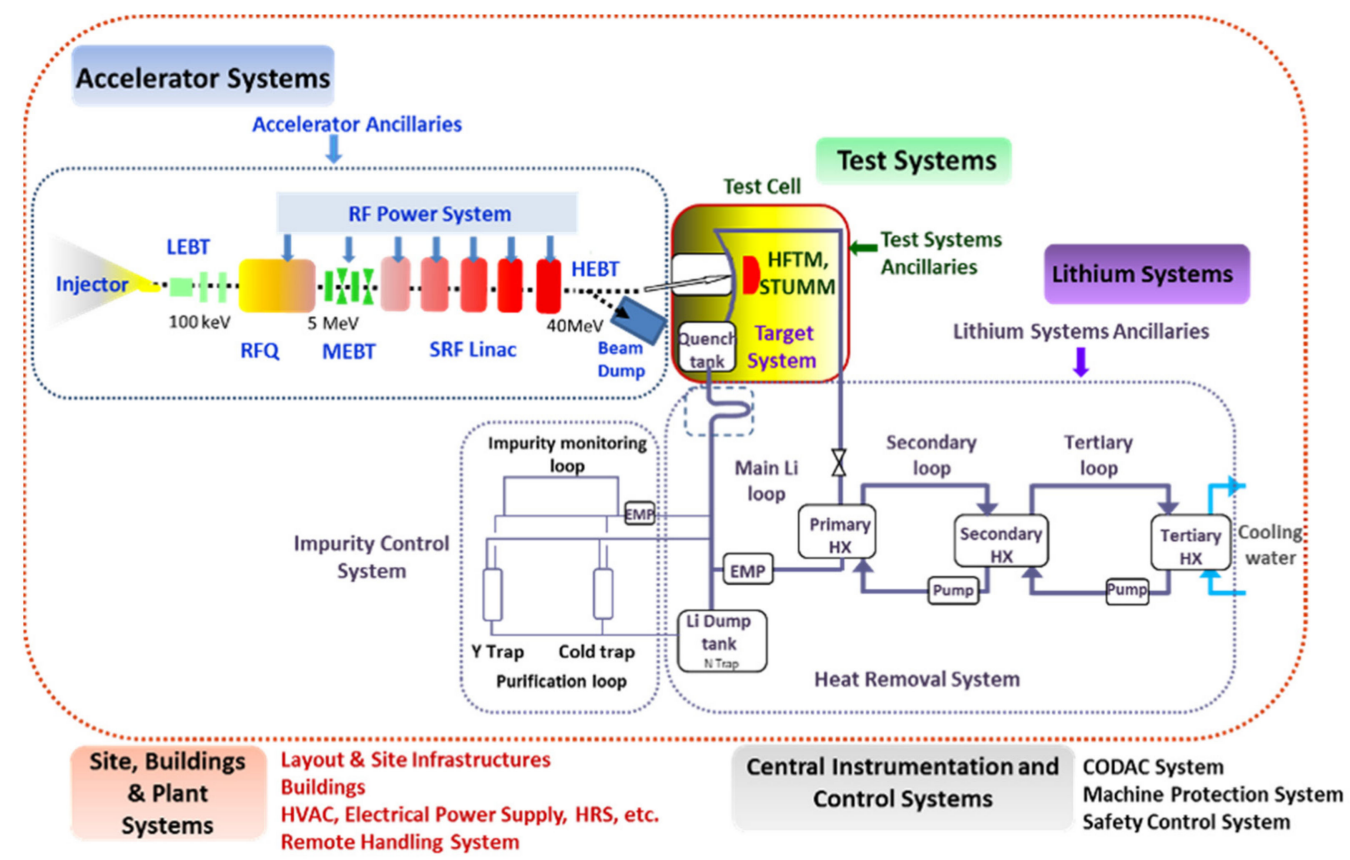

Figure 1. IFMIF-DONES plant system configuration.

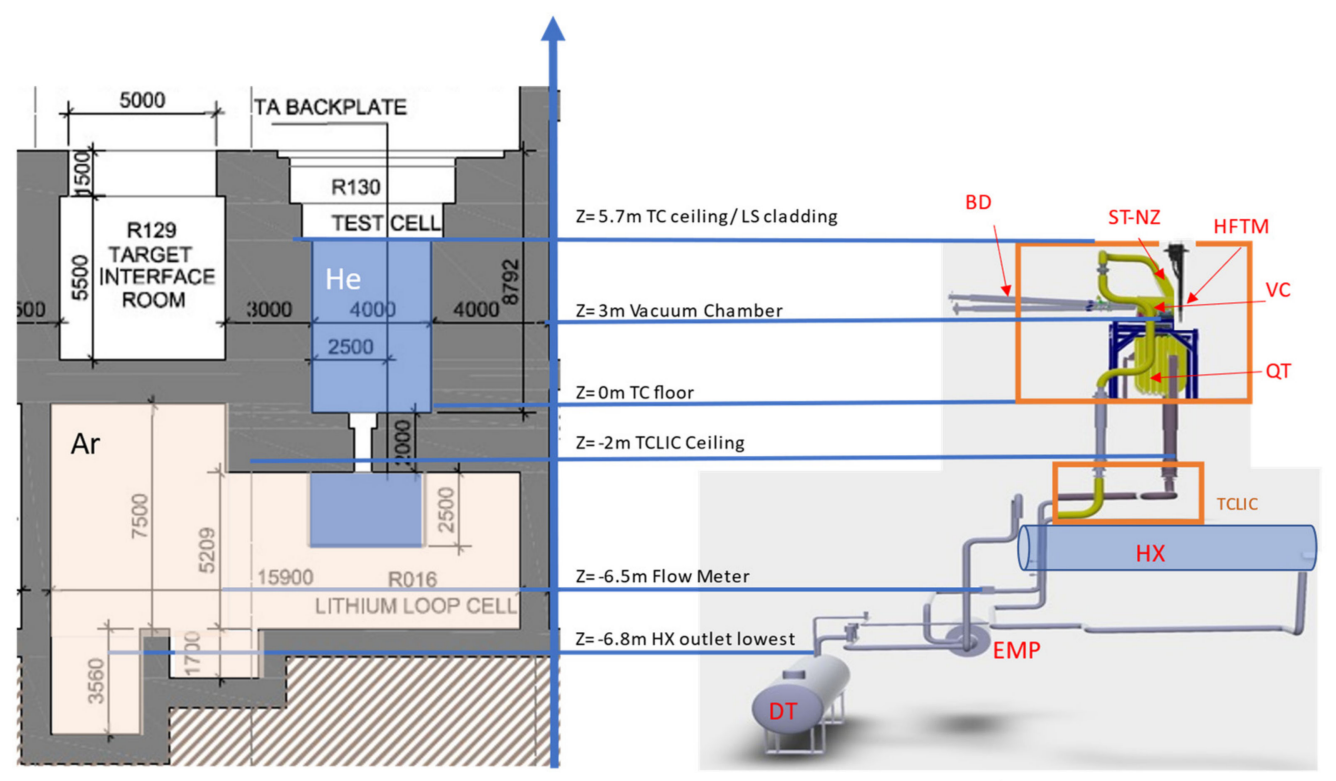

(a)

(b)

Figure 2. (a) Building layout and rooms in scope (light blue). (b) Related Melcor model elevations for considered systems.

\subsection{Accident Specification for the LTTC1 Event}

Accident Analysis Specifications for the accident have been developed to define the analysis scope, methodology, and expected goal. The PIE event considered is LTTC1 Loss of Li in TTC due to a large break in the Quench Tank. The transient sequence initiated by the rupture in the lithium loop running inside the TTC induces the release of liquid metal into the TTC. The TTC atmosphere is filled with inert (Helium) gas and kept at "sub-atmospheric/or slight" pressure; then, no Li-air reaction occurs. Nevertheless, the rupture of the QT induces the release of a large amount of hot lithium in the TTC floor. A liner is foreseen to prevent contact between $\mathrm{Li}$ and the concrete of the TTC structures to mitigate the risks of reactions between $\mathrm{Li}$ and the concrete elements (e.g., water humidity and air). Under the liner, incorporated in the concrete structure, a water-cooling circuit is 
foreseen to prevent heat-up of the TTC during the facility operations. The release of the large Li mass over the liner will start the heat exchanging between the hot lithium and the cold TTC structures. Over-heating and over-pressurization of the water cooling could occur, impairing the cooling loop integrity. The objective of the analysis is to study overpressurization of the TTC volume because of the heating of the He gas contained inside the TTC, the over-heating of the TTC structures (liner and concrete), and the over-heating and over-pressurization of the TTC water cooling system.

Note that no Loss of Off-Site power is assumed to co-occur in the selected initiating event. As safety mitigation system assumptions, the EMP stop and BEAM shutdown have been assumed. The beam power switches off and EMP fully stops after $0.1 \mathrm{~s}$ and $5 \mathrm{~s}$ from the event detection, respectively. The accelerator beam duct is isolated from the target after beam shutdown. Note that in compliance with diversity criterion for safety important classified detection systems, several accident condition detection systems are currently being considered in design (e.g., QT level, pressure in selected volumes, etc.) and are expected to have different detection times depending on the accident.

No valves for the lithium main loop isolation are foreseen, so in order to investigate the possibility of reducing the lithium leaked inventory, the exploitation of a dump tank (normally used to store lithium during loop maintenance or off-line operation) to be opened as a consequence mitigation solution is still under discussion.

\subsection{Simulation Models and Approaches}

MELCOR is a code originally developed for the safety analysis of light water fission reactors. Over the past twenty years, a series of modifications have been implemented to account for nuclear fusion-relevant phenomena [12,13,20,21]. This new MELCOR version validated against available fusion experimental data or benchmarked against validated codes [22-25] has become a reference code for safety analysis in nuclear fusion studies. It has also been adopted for accident analyses exploited for licensing purposes in fusion facilities, the most representative example being ITER $[13,26]$.

More recently, the MELCOR Fusion adapted version 1.8.6-2017 computer code [12] has been exploited for the analysis of integrated HTS containment as part of preliminary safety assessments in pre-conceptual designs of European DEMO concepts [27-30] as well as in Korean DEMO [31]. Being able to model phenomena relevant for fusion safety applications such as radionuclide transport (e.g., tritiated water) in the presence of a variety of cooling fluids (helium, water, liquid metals) as well as pressure conditions (e.g., vacuum), the MELCOR code has been considered for deterministic safety analyses aimed at the licensing of the DONES plant [5,6], showing good agreement with RELAP5 results $[7,32,33]$.

Considering thermal-hydraulic analyses performed within the DONES/IFMIF facilities context, most of the studies have focused on CFD modeling of liquid lithium target with a focus on correctly modeling phenomena such as liquid metal flow, free surface flow under vacuum [34-37] or specific effects resulting from beam/target interactions [38]. This is justified by the many requirements for facility operation relying on the specific conditions that the flowing liquid lithium film will stably achieve. The present application assesses the impact on the containment of a liquid lithium large spillage event. Therefore, despite that liquid metal flow and free surface flow under vacuum are relevant phenomena to reproduce a steady-state regime before the postulated initiating event, the focus is on the heat transfer phenomena occurring at the lithium/liner (Figure 3) and liner/cooling pipe (Figure 4) interfaces. 


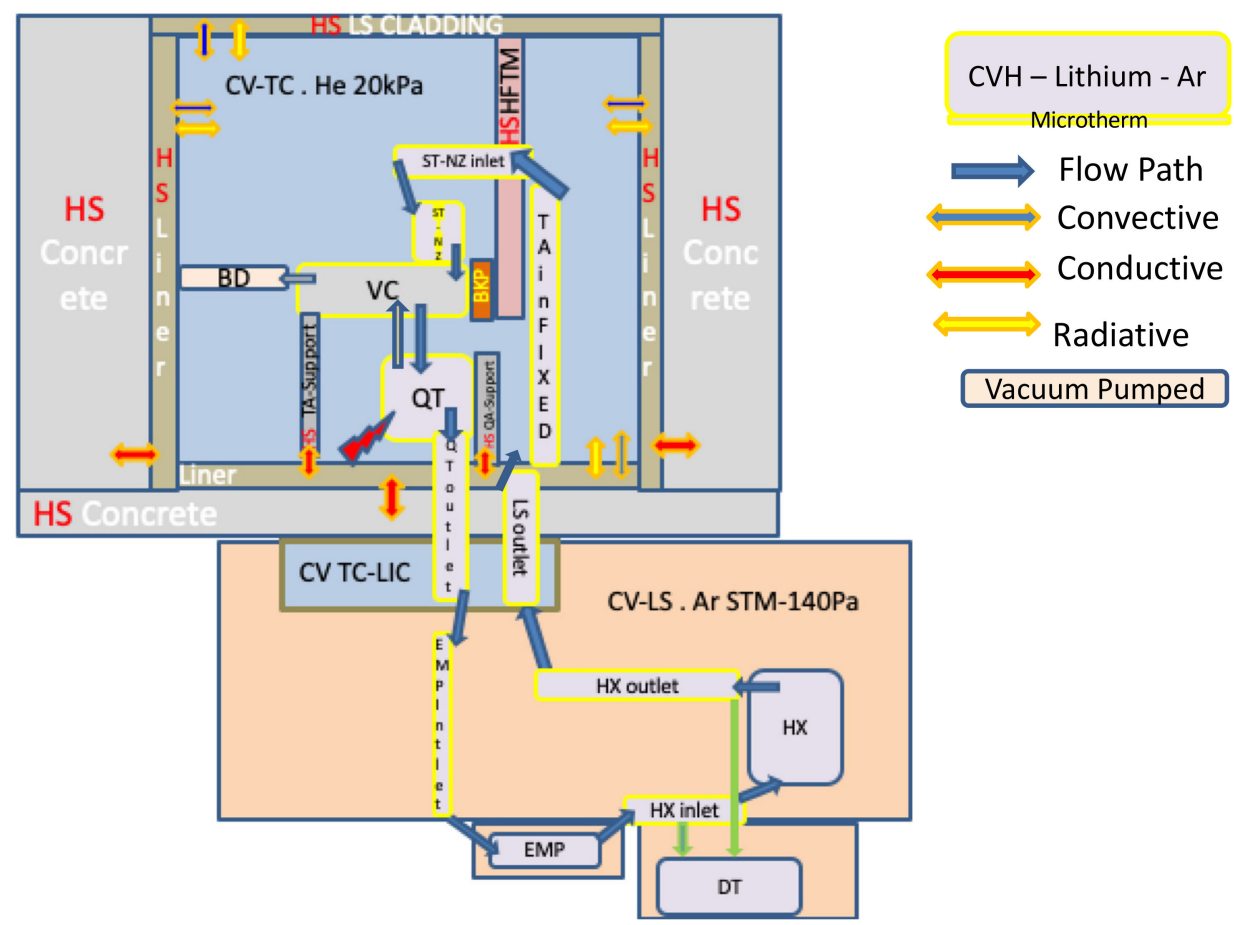

Figure 3. TC-LS Melcor model nodalization.

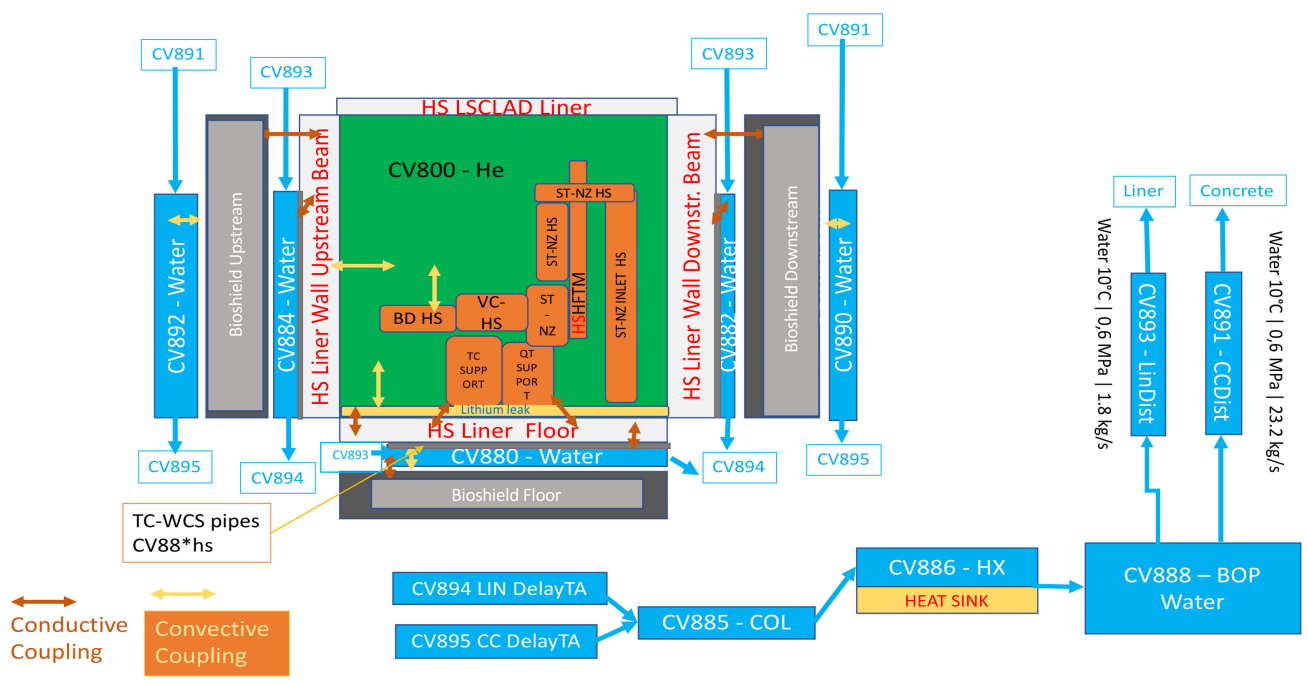

Figure 4. TC-WCS Melcor nodalization.

The MELCOR code has been reputed to be suitable for the present application modeling purpose. In fact, the MELCOR fusion version when lithium is selected as a working fluid includes in the model the thermodynamic and transport properties of lithium other than lithium/air reactions possibly occurring after spills events [10]. In particular, the Equation of State (EOS) was modified to integrate the liquid lithium properties from [39], extrapolation below the triple point, and film formation on cold structures. Refer to [40] for further details on numerical models. These modifications were validated by using Hanford Engineering Development Laboratory (HEDL) experimental data [41,42] as a benchmark. 
An additional feature available in MELCOR fusion exploited in the present analysis is the user-defined function FUN1 to model direct heat transfer (radiation and conduction) between heat structures. Heat power exchanged across heat structures is equal to

$$
Q=S \cdot\left(f \cdot \frac{k_{s}}{d x}\right)\left(T_{1}-T_{2}\right)+(1-f) \cdot \varepsilon \cdot \sigma \cdot\left(T_{1}^{4}-T_{2}^{4}\right)
$$

with $\mathrm{S}$ surface of heat exchange across structures, $T_{1}$ and $T_{2}$ are the considered heat structure surface temperatures, $f$ is the fraction of such surfaces in conductive contact, $\varepsilon$ is emissivity, the Stefan-Boltzmann constant is $\sigma, \mathrm{dx}$ is the distance across a solid, and $k_{s}$ is the thermal conductivity. In the present analysis, the DBA version of the MELCOR code has been used.

Unfortunately, the current MELCOR version does not allow for contemporary usage of two cooling fluids such as lithium (used in the LS main loop) and water (used in TC -WCS). Therefore, to have a preliminary study providing future reference for the upcoming Melcor-TMAP integrated version able to treat multiple fluids [42], the exploited approach was:

1. Implement a MELCOR input deck to estimate the leaked lithium inventory, modeling TC, TA, and LS systems and using lithium as a working fluid.

2. Implement a separate MELCOR model including the TC and TC-WCS systems to simulate TC wall cooling and using water as a working fluid.

3. Implement a numerical coupling of the two models running in parallel and exchanging respective boundary conditions relative to the TC floor liner as an interfacing heat structure of interest.

Details about the MELCOR model nodalization and coupling approach are provided in the following subsections.

\subsubsection{Nodalization of TC and LS with the Lithium Working Fluid}

With reference to Figure 2, the first implemented model considered TC and TCLIC rooms with a Helium atmosphere and LS main loop room filled with an Argon atmosphere. As outlined in (Figure 3), the adopted nodalization includes a TC room, TA volumes, LS main loop volumes, beam duct $\left(0.8 \mathrm{~m}^{3}\right)$, vacuum chamber $\left(0.36 \mathrm{~m}^{3}\right)$, and some service volumes such as the environment or vacuum supply volume.

The main lithium loop has a total inventory (Table 1) of $7.4 \mathrm{~m}^{3}$ of lithium in the liquid phase at $523.15 \mathrm{~K}$, set as the working fluid for the MELCOR code. The loop initially contains an argon atmosphere; then, the vacuum is pumped at start-up and EMP is started. After start-up, the loop reaches a reference operative parameter, i.e.,: $49.8 \mathrm{~kg} / \mathrm{s}$ of lithium mass flow rate, $1.43 \mathrm{~m}$ liquid level within QT. Then, the beam is operated and injects 5.E6 W power into the lithium film, increasing the liquid lithium temperature from $523.15 \mathrm{~K}$ at the HX outlet to $546.15 \mathrm{~K}$ within QT. Note that for comparability's sake and whenever possible, the same CV names and safety logic were used as in [6]. The break was assumed to occur at the bottom of the QT in correspondence with the QT outlet flange. The break area was assumed to be the outlet pipe section $\left(0.0314 \mathrm{~m}^{2}\right)$, assumed to open at $\mathrm{t}=1000 \mathrm{~s}$ after a stationary operation period. Figure 3 also shows the considered heat structure general scheme and heat transfer coupling phenomena. Each CV within the main lithium loop was provided with heat structures representing stainless steel piping or component walls. Pipes were covered with $0.04 \mathrm{~m}$ of MICROTHERM ${ }^{\circledR}$ pipe-insulating material (shown in Figure 3 with a yellow contour) to reduce lithium loop heat losses towards the room atmosphere in the TC and lithium area. A set of additional structures representing TC structures were also defined. In particular, BP and HFTM structures (made of Eurofer) and TA and TC support structures (made of Stainless Steel) and assumed to be in thermal conductivity with the liner floor. LSP Cladding acting as a TC ceiling and HTFM module were helium-cooled. Since the helium cooling loop is not considered within scope, those HSs were modeled as boundary condition structures with a fixed temperature. Test cell heat structure details 
are reported in Table 2. Convective and radiative heat exchange between heat structures and the surrounding atmosphere was considered. A conductive coupling was considered across selected structures (as shown in Figure 3) and modeled using MELCOR FUN1. Two heat structures modeled the TC lateral wall, one upstream target plane with respect to the beam source and one downstream. This choice was made to account for different nuclear heating and decay heat conditions $[43,44]$ in the two zones.

Table 1. Lithium inventory. ${ }^{*}$ DT volume is empty during operation.

\begin{tabular}{cccc}
\hline Lithium Inventory & Description & Length $[\mathbf{m}]$ & Vol $\left.^{\mathbf{3}} \mathbf{]}\right]$ \\
\hline \multirow{4}{*}{ Piping primary loop } & Pipe LS-TLIC & 14.7 & 0.27 \\
& Pipe LS-EMP outlet & 13.1 & 0.24 \\
& Pipe LS-HX outlet & 17.7 & 0.33 \\
& Pipe LS outlet-TLIC & 17.6 & 0.33 \\
& Pipe LS-TLIC-LSRoom & 8.4 & 0.16 \\
\hline Piping target & ST-NZ Inlet Fixed pipe & 5.8 & 0.11 \\
assembly & ST-NZ Inlet Removable pipe & 2.2 & 0.04 \\
\hline \multirow{2}{*}{ Equipment } & ST-NZ & & 0.06 \\
& QT & & 1.20 \\
& EMP & & 0.52 \\
& HX & 9.10 \\
\hline Total & DT & & 7.4 \\
\hline
\end{tabular}

Table 2. Heat structures within the Test Cell.

\begin{tabular}{|c|c|c|c|c|c|c|}
\hline Description & Material & $\begin{array}{c}\text { Equivalent } \\
\text { Thickness [m] }\end{array}$ & $\begin{array}{c}\text { Surface } \\
{\left[\mathrm{m}^{2}\right]}\end{array}$ & $\begin{array}{c}\text { Initial } \\
\text { Temperature [K] }\end{array}$ & $\begin{array}{c}\text { Nuclear Heating } \\
{[W]}\end{array}$ & $\begin{array}{c}\text { Decay Heat } \\
{[\mathrm{W}]}\end{array}$ \\
\hline Liner Floor (HS80001) & Stainless Steel & 0.008 & 8.4 & 283.15 & 373.0 & 8.0 \\
\hline Bioshield Floor & Concrete & 2.0 & 8.4 & 313.0 & 3701.0 & 74.0 \\
\hline Liner Wall downstream beam & Stainless Steel & 0.008 & 33.1 & 283.15 & 4308.0 & 86.0 \\
\hline Liner Wall upstream beam & Stainless Steel & 0.008 & 45.8 & 283.15 & 2532.0 & 50.0 \\
\hline $\begin{array}{c}\text { Bioshield wall downstream } \\
\text { beam }\end{array}$ & Concrete & 1.0 & 33.1 & 293.15 & 56.0 & 1123.0 \\
\hline Bioshield wall upstream beam & Concrete & 1.0 & 45.8 & 322.15 & 27.0 & 546.0 \\
\hline LSP Cladding & Stainless Steel & 0.008 & 11.2 & 333.0 & & \\
\hline HFTM & Eurofer & 0.11 & 1.15 & 349.0 & & \\
\hline Backplate & Eurofer & 0.03 & & 523. & 1085.0 & 22.0 \\
\hline Qt Support & Stainless Steel & 0.01 & 3.51 & 353.0 & 400.0 & 32.0 \\
\hline Tc Support & Stainless Steel & 0.01 & 14.482 & 353.0 & 1448.0 & 116.0 \\
\hline
\end{tabular}

\subsubsection{Nodalization of TC Walls Water Cooling Loop}

A second MELCOR model was implemented for the TC-WCS loop using water as a working fluid. Figure 4 shows the adopted nodalization for the TC/TC-WCS model, heat structures, and heat transfer phenomena. Table 3 reports control volume data. Liner and bio shield walls are cooled by parallel branches. In particular, a main distributor manifold splits the nominal $25 \mathrm{~kg} / \mathrm{s}$ water mass flow into $23.2 \mathrm{~kg} / \mathrm{s}$ flow for the bio shield concrete walls cooling branch and the remaining $1.8 \mathrm{~kg} / \mathrm{s}$ for the liner wall cooling branch. Such branches converge into a unique collector after two separate delay tank volumes allowing for activated water decay before entering HX. An HX removes about $109 \mathrm{~kW}$ power, of which $90 \mathrm{~kW}$ is from the bio shield and the remaining part from the liner. Water at the HX outlet is at $283.15 \mathrm{~K}$ and $0.6 \mathrm{MPa}$. A pump compensates for an estimated pressure drop of $4500 \mathrm{hPa}$ along the loop. Cooling pipes volumes were provided with a 2-mm-stainless steel wall representing pipe walls with which the liner and concrete walls have conductive exchange. 
Table 3. Control Volumes in the TC-WCS loop.

\begin{tabular}{lcccc}
\hline \multicolumn{1}{c}{ Description } & CV & $\begin{array}{c}\text { Pool P } \\
{[\mathbf{P a}]}\end{array}$ & Pool Temperature [K] & Volume [m ${ }^{3}$ ] \\
\hline Floor Liner cooling branch & 880 & $3.50 \times 10^{5}$ & $3.50 \times 10^{5}$ & $4.5 \times 10^{-3}$ \\
Downstream liner cooling branch & 882 & $5.80 \times 10^{5}$ & $5.80 \times 10^{5}$ & $2.89 \times 10^{-2}$ \\
Upstream liner cooling branch & 884 & $4.00 \times 10^{5}$ & $4.00 \times 10^{5}$ & $3.85 \times 10^{-2}$ \\
Main Collector & 885 & $1.50 \times 10^{5}$ & $1.50 \times 10^{5}$ & 1.06 \\
Heat Exchanger & 886 & $1.50 \times 10^{5}$ & $1.50 \times 10^{5}$ & 7.50 \\
Pressurizer & 887 & $1.50 \times 10^{5}$ & $1.50 \times 10^{5}$ & 1.40 \\
Balance volume & 888 & $6.00 \times 10^{5}$ & $6.00 \times 10^{5}$ & 6.00 \\
Downstream Bioshield cooling branch & 890 & $5.80 \times 10^{5}$ & $5.80 \times 10^{5}$ & $1.23 \times 10^{-1}$ \\
Bioshield branch distributor & 891 & & & 1.00 \\
Upstream Bioshield cooling branch & 892 & $3.50 \times 10^{5}$ & $3.50 \times 10^{5}$ & $1.23 \times 10^{-1}$ \\
Liner branch distributor & 893 & $6.00 \times 10^{5}$ & $6.00 \times 10^{5}$ & 1.00 \\
Liner Cooling branch delay tank & 894 & $1.50 \times 10^{5}$ & $1.50 \times 10^{5}$ & 1.00 \\
Concrete Cooling branch delay tank & 895 & $1.50 \times 10^{5}$ & $1.50 \times 10^{5}$ & 1.00 \\
\hline
\end{tabular}

\subsubsection{Numerical Coupling of the Two Models}

Several working fluids are available in the MELCOR 1.8.6 code; however, for a given problem, only one of these fluids can be used (together with non-condensable gases). Thus, obvious challenges have been encountered during the modeling phase of the DONES facility since both lithium and water coolants could not be used in a single run.

A possible solution is represented by the external coupling through a Python script of two separate MELCOR input decks, one working with lithium and the other one with water. The two models run concurrently, and information is exchanged between them. Figure 5 represents the approach implemented to couple the TC-LS and TC-WCS Melcor models.

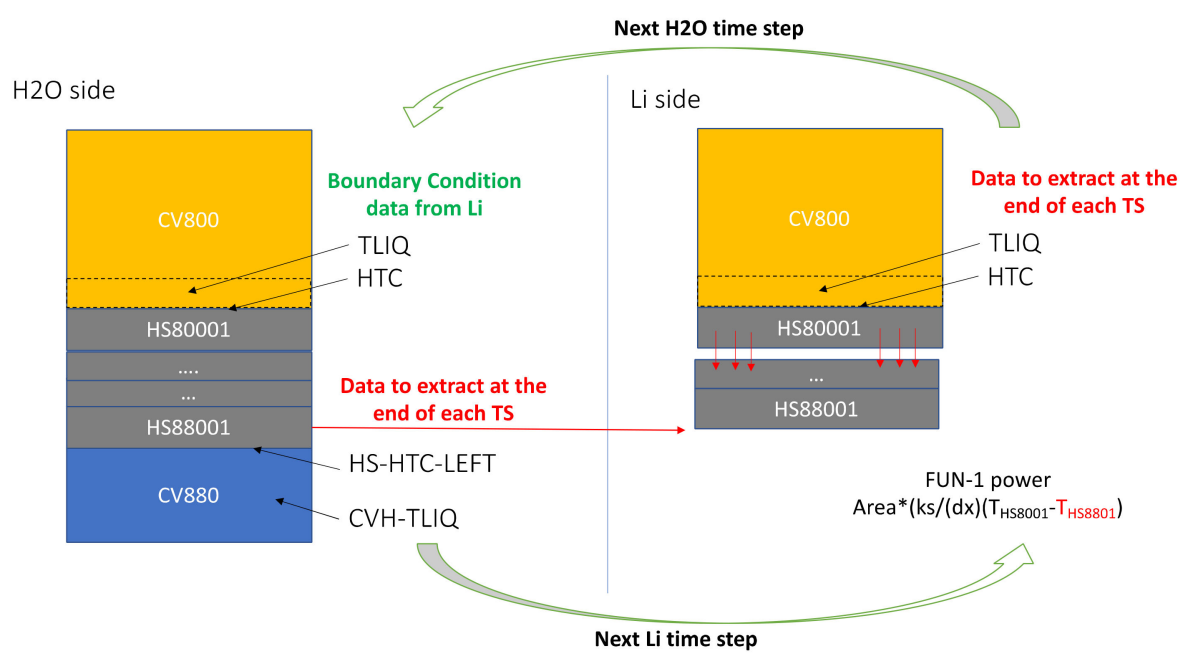

Figure 5. Scheme of numerical coupling between TC-LS and TC-WCS Melcor models.

In the Python script, information regarding the heat exchange between the two fluids is collected. In each MELCOR input, a heat structure and two control volumes are present. One of the control volumes contains the working fluid, while the other is a time-dependent control volume that simulates the other fluid involved in the heat transfer. In this control volume, as previously described, the properties are specified as a function of time.

During each MELCOR run, the update on the exchanged heat flux is passed from one input to the other, reporting the new heat transfer coefficients and the new temperatures in the heat structure and in the time-dependent control volume, respectively. Indeed, the temperature of the time-dependent volume will be the temperature assumed by the fluid 
of the other input at the previous time step. The exchange of information between the MELCOR inputs is obtained by writing in external files (External Data File or EDF) the variables of interest, i.e., temperatures and heat transfer coefficients in this case, after they have been saved in the Python script after a single run. Thus, the heat transfer coefficients are given as a type of boundary condition applied at the left or right boundary surface of the heat structure. In this case, a convective boundary condition is applied with the heat transfer coefficients specified by the Control Function in which the value is reported through the EDF. Instead, the temperatures are directly introduced into the time-dependent volumes directly through the EDF. To clarify this with an example referring to Figure 5 (left side), $\mathrm{CV} 800_{\mathrm{H} 2 \mathrm{Oinput}}$ is the time-dependent volume representing the $\mathrm{CV}$ containing lithium in the $\mathrm{H} 2 \mathrm{O}$ input and the HS80001 heat structure simulating the liner, and the power transferred to $\mathrm{HS} 80001$ is equal to $\mathrm{Q}=\mathrm{HTC}_{\mathrm{Linnut}}\left(\mathrm{TLIQ}_{\mathrm{Li} \text { input }}-\mathrm{T}_{\mathrm{HS} 80001}\right) \mathrm{A}_{\mathrm{HS} 80001}$.

Note that the current design of liner wall cooling considers cooling coils welded to the liner surface. Therefore, cooling power is extracted by means of conduction between the coil pipe surface and liner surface. This was implemented in MELCOR (Figure 5) using a FUN1 function assuming a thermal conductivity $\mathrm{k}_{\mathrm{s}}=10 \mathrm{~W} / \mathrm{mK}$ (order of SS316, accounting for thermal contact resistance) and a distance $\mathrm{dx}$ over which the thermal gradient was calculated to be $8 \mathrm{~mm}$.

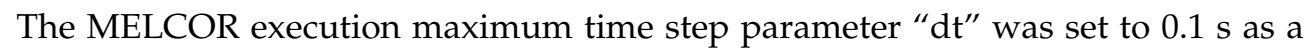
trade-off between the computational time and amount of power exchanged within each time step across heat structures by means of FUN1 functions. In fact, higher values of time steps have been observed to lead to numerical instabilities. The coupling $\mathrm{dt}_{\text {coup }}$ for data extraction was then set accordingly.

Note that a $60,000 \mathrm{~s}$ stationary regime simulation period was considered to reach a steady-state for the TC-WCS loop before the PIE event in the TC-LS simulation. Numerical coupling starts at 60,000 s for the TC-WCS loop, $1000 \mathrm{~s}$ before PIE occurrence set at 61,000 s.

\section{Results and Discussion}

Model validation in the two cases was at first performed on the basis of selected parameters. For the main lithium loop, the adopted parameters were (i) Li temperature at target inlet $522.68 \mathrm{~K}(523 \mathrm{~K}$ nominal), (ii) Li mass flow rate $49.5 \mathrm{~kg} / \mathrm{s}(49.8 \mathrm{~kg} / \mathrm{s}$ nominal), (iii) Li level in QT $1.39 \mathrm{~m}$ (1.43 m nominal at steady state), and iv) Li temperature in QT at $546 \mathrm{~K}$ ( $546.7 \mathrm{~K}$ nominal). Concerning the TC-WCS cooling loop, it should be noted that its design stage is pre-conceptual and not detailed. Thus, the model validation during the stationary regime was performed on available dimensioning parameter expected values: (i) mass flow rate at distributors: $1.8 \mathrm{~kg} / \mathrm{s}$ and $22.5 \mathrm{~kg} / \mathrm{s}$ for liners and concrete distributors, respectively (in good agreement with nominal values reported in Section 2.3.2); (ii) liner temperatures (HS-80001, HS-80003, HS80004) within $\pm 1 \%$ from nominal value of $283.15 \mathrm{~K}$.

After model validation, a first assessment of the LTTC1 event in terms of released inventory and consequences on the TC atmosphere was performed. After a steady-state period with the loop fully active and beam operating, the PIE occurred at time $t=1000 \mathrm{~s}$. A sensitivity analysis was performed on PIE detection sensors and the mitigation device. Note that for the considered PIE, detections upstream QT might result in late detection, since perturbation of the main LS loop parameters is firstly propagated to downstream QT. A selection of the main accident detection sensors considered to initiate the beam stop procedure is reported in Table 4. 
Table 4. Accident detection.

\begin{tabular}{ccc}
\hline Sensor & Triggering Condition & $\begin{array}{c}\text { Time of Occurrence } \\
\text { Since PIE [s] }\end{array}$ \\
\hline $\begin{array}{c}\text { Target Vacuum Chamber Gas } \\
\text { Pressure }\end{array}$ & $\begin{array}{c}\mathrm{TC}_{\text {pressure }} \geq 1 \mathrm{kPa} \text { (approx. } 10 \times \\
\text { nominal pressure })\end{array}$ & 0.22 \\
Pressure in TC & $\begin{array}{c}\text { Increase } 10 \% \text { with respect to nominal } \\
\text { Liner Floor Temperature }>393 \mathrm{~K}(100 \mathrm{~K}\end{array}$ & 2 \\
over nominal) & 13.0 \\
Quench Tank Li-Level & $\mathrm{QT}_{\text {level }} \leq 0.715 \mathrm{~m}(50 \%$ nominal value $)$ & 21.9 \\
\hline
\end{tabular}

Given the goal of this simulation (i.e., to investigate the liner temperature rise and underlying cooling loop pressurization), the results from the case with a slower detection were conservatively considered.

Figure 6 shows the mass flow rate transient at PIE for selected flow paths judged relevant (break flow path, straightener inlet, and EMP outlet). Note that after EMP stop triggered by accident detection, the mass flow rate in the loop gradually decreases from the steady-state value $(49.5 \mathrm{~kg} / \mathrm{s})$ until an inversion occurs due to relative elevations of EMP and the target (refer to Figure 2). This limits the released lithium mass inventory to about $729 \mathrm{~kg}$ (Figure 7), slightly more than the steady-state inventory within the QT (562 kg).

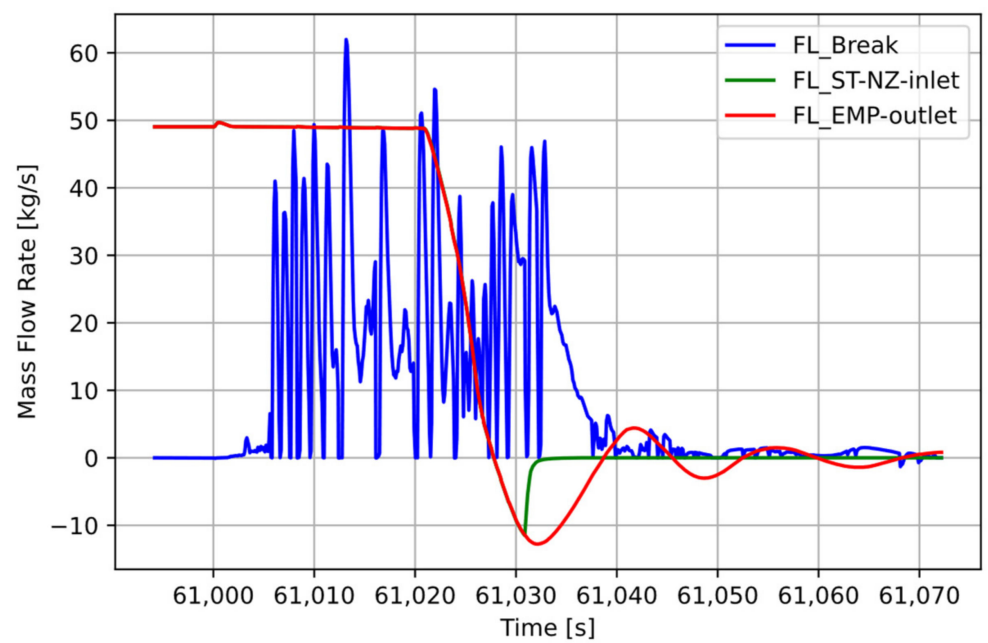

Figure 6. Mass flow rate for selected flow paths for break (FL801), removable ST-NZ inlet (FL852), and EMP (FL350).

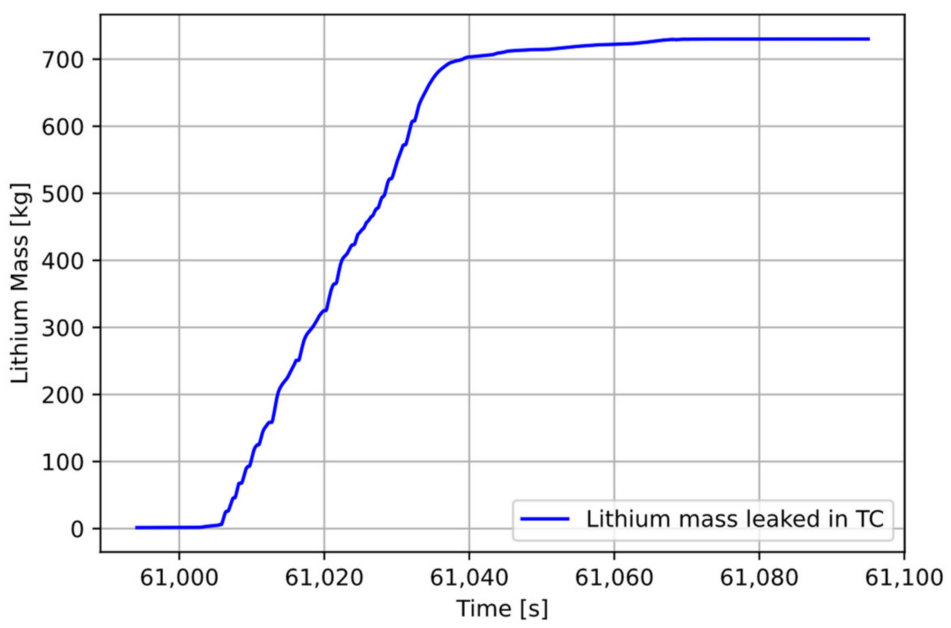

Figure 7. Inventory in QT(CVH850) and released in TC (CVH800). 
The pressure wave form of the TC containment after PIE is shown in Figure 8. The pressure peak reaches $33 \mathrm{kPa}$ within $8 \mathrm{~s}$, then starts a decreasing pattern within $100 \mathrm{~s}$ from PIE.

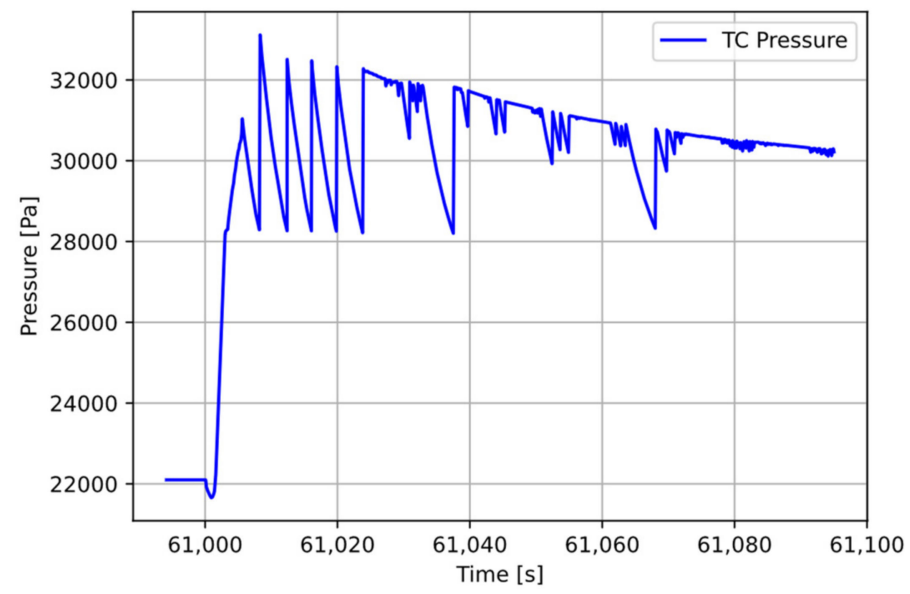

Figure 8. Pressurization of TC after PIE.

Figure 9 focuses on the temperatures on the liner floor and related cooling systems. Leaked lithium is released at a temperature of $546 \mathrm{~K}$ and then quickly cools down once in contact with the liner floor. In turn, the liner floor quickly passes from the $287 \mathrm{~K}$ temperature before PIE, to $463 \mathrm{~K}$ within $50 \mathrm{~s}$, peaking at $472 \mathrm{~K}$ within $220 \mathrm{~s}$. As a consequence, the underlying cooling pipe HS and water coolant reach $460 \mathrm{~K}$.

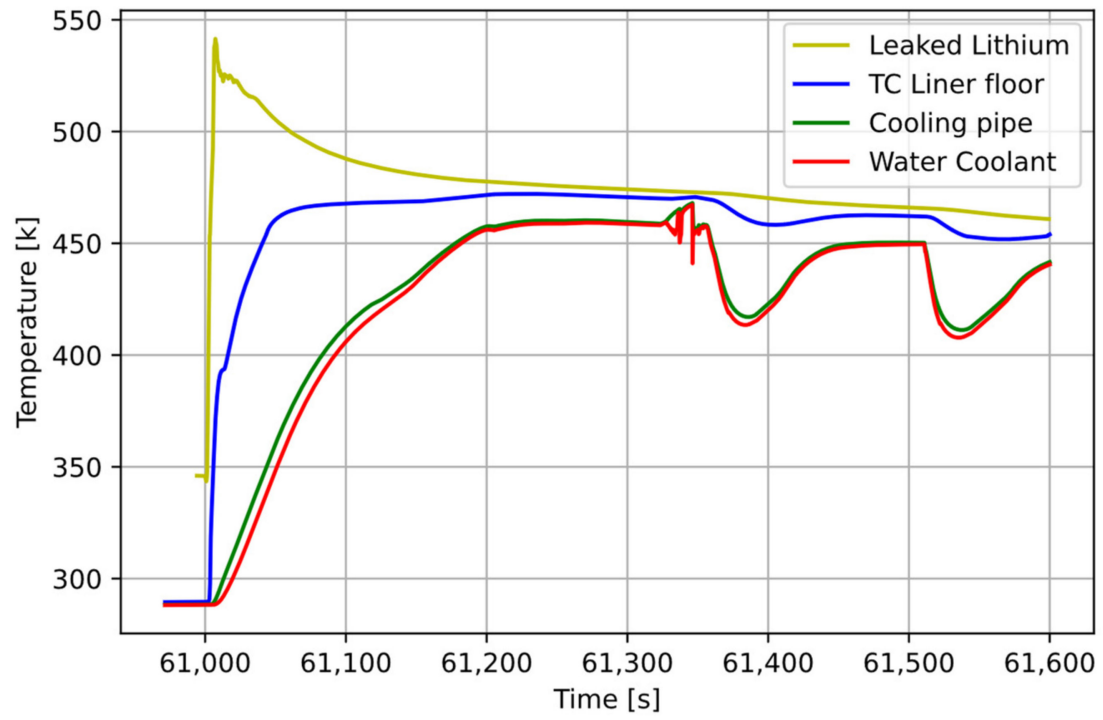

Figure 9. Liner floor, underlying water pipes, and water coolant temperature after PIE.

Figure 10 shows that water within the liner floor cooling loop vaporizes after about $350 \mathrm{~s}$, causing a temporary loss of coolant mass from the CV880 volume, as shown in Figure 11. The mentioned vaporization results in the pressurization pattern shown in Figure 12, though gradually absorbed by the loop within 500 s from PIE. 


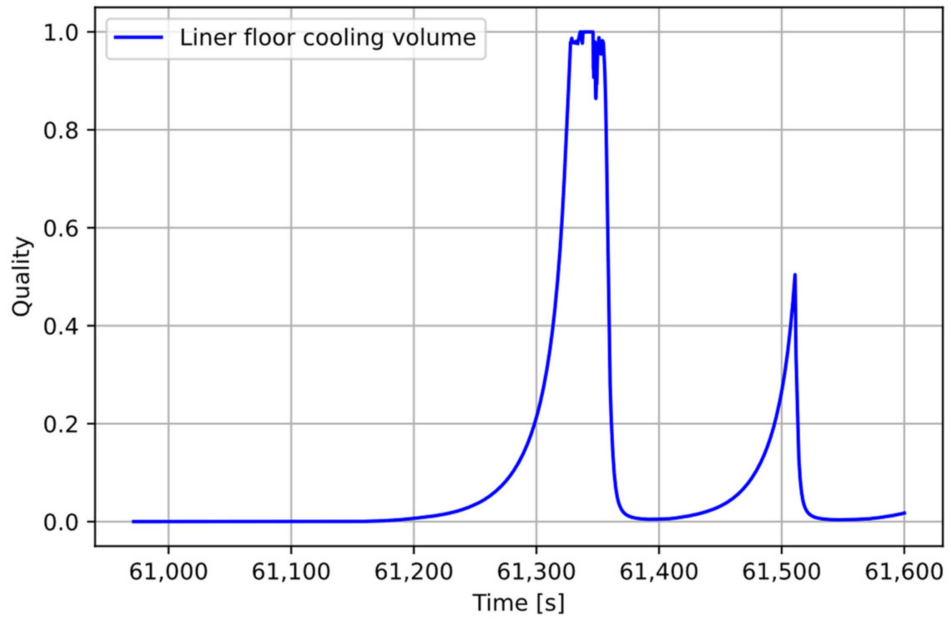

Figure 10. Water steam quality within liner floor cooling loop water pipes.

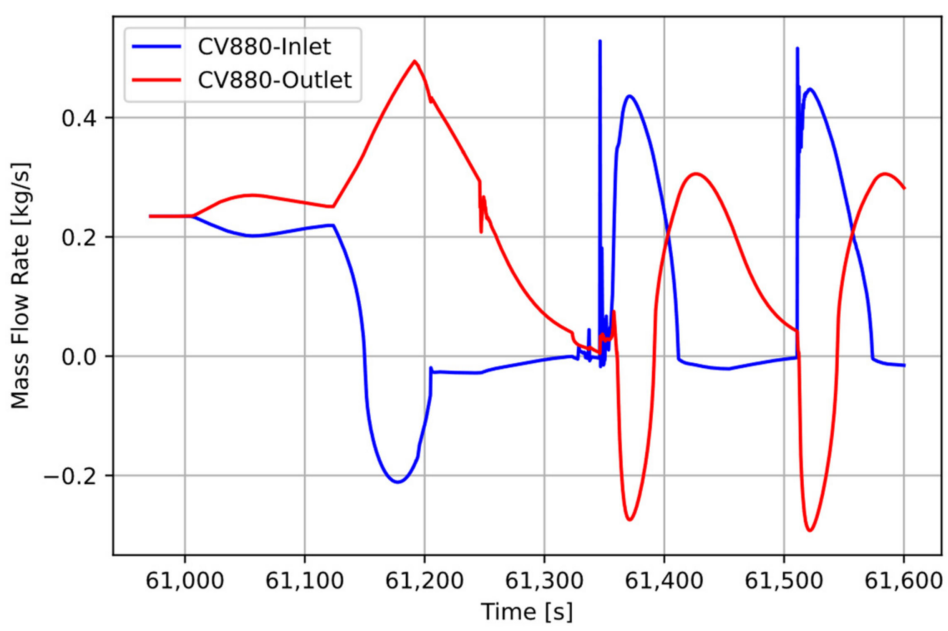

Figure 11. Flow mass rate at the liner floor cooling volume inlet/outlet.

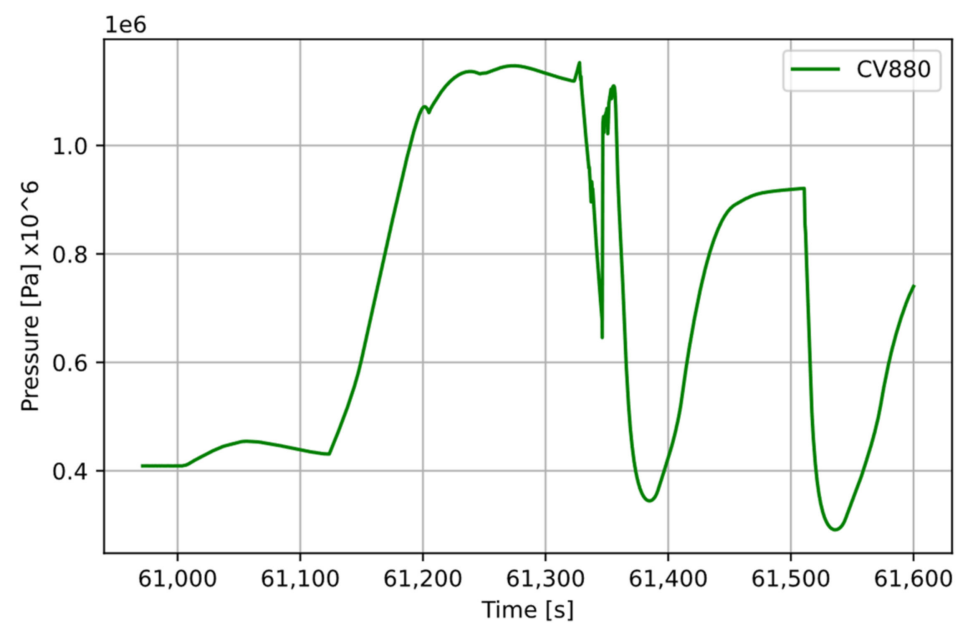

Figure 12. Water coolant pressure in the liner cooling loop water pipes after PIE.

\section{Conclusions}

An analysis of the impact of a liquid lithium spillage event on room containment has been proposed. In particular, the purpose of this study was to investigate consequences on the water-cooled steel liner floor of the containment room with a possible breach of the 
liner barrier enabling lithium to contact the underlying concrete or water itself in the case of cooling pipe rupture. Considering the impact of presented transients in terms of safety consequences, the TC pressurization does not appear to be a concern for the TC containment. In fact, despite the occurrence of water vaporization transient in the cooling loop under the floor liner, the reached pressure peak at about 1.14 MPa appears withstandable within the cooling pipe design pressure. Therefore, the break of cooling pipes and consequent release of water appear unlikely. Given the high temperature difference between released liquid lithium inventory $(546 \mathrm{~K})$ and liner temperature $(287 \mathrm{~K})$, the temperature rise has a steep pattern reaching more than $3 \mathrm{~K} / \mathrm{s}$ temperature rise velocity. Future work shall investigate liner structural resistance to such thermal shock events [45-47], possibly leading to liner failure and lithium contacting the concrete. However, even in the case of such a concrete-lithium contact event, lithium at such an interface point would likely be in solid phase or below the minimal observed ignition point (453.15 K) [8], making a consequent fire event unlikely. Future work will also investigate model sensitivity [48] to specific parameters impacting the liner model as the interface point (e.g., thermal conductivity at the liner/cooling pipe contact point, cooling pipe exchange surface).

Author Contributions: Conceptualization, D.N.D.; methodology, D.N.D. and M.D.; software, D.N.D. and M.D.; validation, D.N.D. and M.D.; writing—original draft preparation, D.N.D.; writing-review and editing, D.N.D. and M.D. All authors have read and agreed to the published version of the manuscript.

Funding: This work has been carried out within the framework of the EUROfusion Consortium and has received funding from the Euratom research and training programme 2014-2018 and 2019-2020 under grant agreement No 633053. The views and opinions expressed herein do not necessarily reflect those of the European Commission.

Institutional Review Board Statement: Not applicable.

Informed Consent Statement: Not applicable.

Conflicts of Interest: The authors declare no conflict of interest. The funders had no role in the design of the study; in the collection, analyses, or interpretation of data; in the writing of the manuscript, or in the decision to publish the results.

$\begin{array}{ll}\text { Nomenclature } \\ \text { BP } & \text { Back Plate } \\ \text { CV } & \text { Control Volume } \\ \text { EMP } & \text { Electromagnetic Pump } \\ \text { HEBT } & \text { High Energy Beam Transport. } \\ \text { HFTM } & \text { High Flux Test Module } \\ \text { HX } & \text { Heat Exchanger } \\ \text { LEBT } & \text { Low Energy Beam Transport } \\ \text { LS } & \text { Lithium System } \\ \text { LSP } & \text { Lower Shielding Plug } \\ \text { MEBT } & \text { Medium Energy Beam Transport } \\ \text { QT } & \text { Quench Tank } \\ \text { RFQ } & \text { Radiofrequency Quadrupoles } \\ \text { SRF } & \text { Superconducting Radiofrequency } \\ \text { ST-NZ } & \text { Straightener Nozzle } \\ \text { STUMM } & \text { Start-up Monitoring Module } \\ \text { TA } & \text { Target Assembly } \\ \text { TC-WCS } & \text { Test Cell Water Cooling System } \\ \text { TTC } & \text { Target Test Cell } \\ \text { VC } & \text { Vacuum Chamber }\end{array}$




\section{References}

1. Linke, J.; Du, J.; Loewenhoff, T.; Pintsuk, G.; Spilker, B.; Steudel, I.; Wirtz, M. Challenges for plasma-facing components in nuclear fusion. Matter Radiat. Extrem. 2019, 4, 056201. [CrossRef]

2. Federici, G.; Biel, W.; Gilbert, M.R.; Kemp, R.; Taylor, N.; Wenninger, R. European DEMO design strategy and consequences for materials. EURATOM Nucl. Fusion 2017, 57, 9. [CrossRef]

3. Ibarra, A.; Arbeiter, F.; Bernardi, D.; Cappelli, M.; Garcia, A.; Heidinger, R.; Krolas, W.; Fischer, U.; Martin-Fuertes, F.; Micciché, G.; et al. The IFMIF-DONES project: Preliminary engineering design. Nucl. Fusion 2018, 58, 105002. [CrossRef]

4. Federici, G.; Bachmann, C.; Barucca, L.; Biel, W.; Boccaccini, L.; Brown, R.; Bustreo, C.; Ciattaglia, S.; Cismondi, F.; Coleman, M.; et al. DEMO design activity in Europe: Progress and updates. Fusion Eng. Des. 2018, 136, 729-741. [CrossRef]

5. Martín-Fuertes, F.; García, M.E.; Fernández, C.; D’Ovidio, G.; Pinna, T.; Porfiri, M.T.; Fischer, U.; Ogando, F.; Mota, F. Integration of Safety in IFMIF-DONES Design. Safety 2019, 5, 74. [CrossRef]

6. D'Ovidio, G.; Martín-Fuertes, F. Accident analysis with MELCOR-fusion code for DONES lithium loop and accelerator. Fusion Eng. Des. 2019, 146, 473-477. [CrossRef]

7. Arena, P.; Di Maio, P.A.; Nitti, F.S. Safety analysis of the dones primary heat removal system. Fusion Eng. Des. 2020, 161, 112002. [CrossRef]

8. Piet, S.; Jeppson, D.; Muhlestein, L.; Kazimi, M.; Corradini, M. Liquid metal chemical reaction safety in fusion facilities. Fusion Eng. Des. 1987, 5, 273-298. [CrossRef]

9. Barnett, S.; Kazimi, M.J. Consequences of a Lithium Spill in-Side the Containment and Vacuum Torus of a Fusion Reactor; PFC/RR-87-9; MIT Plasma Fusion Center: Cambridge, MA, USA, 1987.

10. Merrill, B.J. A lithium-air reaction model for the melcor code for analyzing lithium fires in fusion reactors. Fusion Eng. Des. 2001, 54, 485-493. [CrossRef]

11. Dongiovanni, D.N.; Porfiri, M.T. Exploratory fire analysis in DONES lithium system. Fusion Eng. Des. 2020, 156, 111680. [CrossRef]

12. Merrill, B.J.; Humrickhouse, P.; Moore, R.L. A recent version of MELCOR for fusion safety applications. Fusion Eng. Des. 2010, 85, 1479-1483. [CrossRef]

13. Merrill, B.J.; Humrickhouse, P.; Shimada, M. Recent development and application of a new safety analysis code for fusion reactors. Fusion Eng. Des. 2016, 109-111, 970-974. [CrossRef]

14. Gauntt, R.O.; Cash, J.E.; Cole, R.K.; Erickson, C.M.; Humphries, L.L.; Rodriguez, S.B.; Young, M.F. MELCOR Computer Code Manuals Vol. 1: Primer and Users; Guide Version 1.8.6, NUREG/CR-6119, Volume 1, Rev. 3; Sandia National Laboratory: Princeton, NJ, USA, 2005.

15. Arbeiter, F.; Diegele, E.; Fischer, U.; Garcia, A.; Ibarra, A.; Molla, J.; Mota, F.; Möslang, A.; Qiu, Y.; Serrano, M.; et al. Planned material irradiation capabilities of IFMIF-DONES. Nucl. Mater. Energy 2018, 16, 245-248. [CrossRef]

16. Tian, K.; Ahedo, B.; Arbeiter, F.; Barrera, G.; Ciupinski, L.; Dézsi, T.; Horne, J.; Kovács, D.; Molla, J.; Mota, F.; et al. Overview of the current status of IFMIF-DONES test cell biological shielding design. Fusion Eng. Des. 2018, 136, 628-632. [CrossRef]

17. Nitti, F.; Ibarra, A.; Ida, M.; Favuzza, P.; Furukawa, T.; Groeschel, F.; Heidinger, R.; Kanemura, T.; Knaster, J.; Kondo, H.; et al. The design status of the liquid lithium target facility of IFMIF at the end of the engineering design activities. Fusion Eng. Des. 2015, 100, 425-430. [CrossRef]

18. Arena, P.; Bernardi, D.; Di Maio, P.A.; Frisoni, M.; Gordeev, S.; Miccichè, G.; Nitti, F.S.; Ibarra, A. The design of the DONES lithium target system. Fusion Eng. Des. 2019, 146, 1135-1139. [CrossRef]

19. Simon, S.; Dézsi, T.; Arbeiter, F.; Tóth, M.; Castellanos, J.; Ibarra, A. Thermal-hydraulic simulation of IFMIF-DONES Test Cell atmosphere. Fusion Eng. Des. 2021, 167, 112336. [CrossRef]

20. Merrill, B.J. 'Recent Updates to the MELCOR 1.8.2 Code for ITER Applications,' INL/EXT-07-12493, May 2007. Available online: https:/ / inldigitallibrary.inl.gov/sites/sti/sti/3644018.pdf (accessed on 30 September 2021).

21. Merrill, B.; Moore, R.; Polkinghorne, S.; Petti, D. Modifications to the MELCOR code for application in fusion accident analyses. Fusion Eng. Des. 2000, 51-52, 555-563. [CrossRef]

22. Topilski, L.; Masson, X.; Porfiri, M.; Pinna, T.; Sponton, L.-L.; Andersen, J.; Takase, K.; Kurihara, R.; Sardain, P.; Girard, C. Validation and benchmarking in support of ITER-FEAT safety analysis. Fusion Eng. Des. 2001, 54, 627-633. [CrossRef]

23. Moore, R.L. Status Report on an ITER ITA on Comparison of MELCOR 1.8.5 Results to MELCOR 1.8.2 Results for a Selected Set of Accident Analysis Cases Relevant to ITER FEAT; EDF-5470, Rev. 11; Idaho National Laboratory: Idaho Falls, ID, USA, 2003.

24. Merrill, B.J. Benchmarking MELCOR 1.8.2 for ITER Against Recent EVITA Results; Idaho National Laboratory: Idaho Falls, ID, USA, 2007. [CrossRef]

25. Sallus, L.; Van Hove, W. MELCOR Code Validation on HE-FUS3. Loop 2008, 391-404. [CrossRef]

26. Merrill, B.J.; Humrickhouse, P.W.; Moore, R.L. “A Comparison of Modifications to MELCOR Versions 1.8.2 and 1.8.6 for ITER Safety Analysis", INL/EXT-09-16715, June 2010. Available online: https:/ /inldigitallibrary.inl.gov/sites/sti/sti/4536702.pdf (accessed on 30 September 2021).

27. Reyes, S.; Topilski, L.; Taylor, N.; Merrill, B.J.; Sponton, L.-L. Updated Modeling of Postulated Accident Scenarios in ITER. Fusion Sci. Technol. 2009, 56, 789-793. [CrossRef]

28. Dongiovanni, D.N.; Pinna, T.; Porfiri, M.T. DEMO Divertor preliminary safety assessment. Fusion Eng. Des. 2021, $169,112475$. [CrossRef] 
29. Jin, X.Z. BB LOCA analysis for the reference design of the EU DEMO HCPB blanket concept. Fusion Eng. Des. 2018, 136, 958-963. [CrossRef]

30. D'Onorio, M.; Giannetti, F.; Caruso, G.; Porfiri, M.T. In-box LOCA accident analysis for the European DEMO water-cooled reactor. Fusion Eng. Des. 2019, 146, 732-735. [CrossRef]

31. Gonfiotti, B.; Paci, S. Normal and Accidental Scenarios Analyses with MELCOR 1.8.2 and MELCOR 2.1 for the DEMO HeliumCooled Pebble Bed Blanket Concept. Sci. Technol. Nucl. Install. 2015, 2015, 1-9. [CrossRef]

32. Moon, S.; Sung, B.; Bang, I.C. Thermal Hydraulic Analysis of K-DEMO Single Blanket Module for Preliminary Accident Analysis using MELCOR. In Proceedings of the KNS 2016 Spring Meeting, Jeju, Korea, 12 May 2016.

33. Murgatroyd, J.T.; Owen, S.; Grief, A.; Panayotov, D.; Saunders, C. Qualification of MELCOR and RELAP5 models for EU HCPB TBS accident analyses. Fusion Eng. Des. 2017, 124, 1251-1256. [CrossRef]

34. Dobromir Panayotov Brad, J. Merrill, From Fission Nuclear Power Plants to Fusion Power Plant Safety Accident Analyses Challenges. In Proceedings of the 1st International Workshop on Environmental, Safety and Economic Aspects of Fusion Power, Jeju, Korea, 13 September 2015. [CrossRef]

35. Pena, A.; Esteban, G.; Sancho, J.; Kolesnik, V.; Abánades, A. Hydraulics and heat transfer in the IFMIF liquid lithium target: CFD calculations. Fusion Eng. Des. 2009, 84, 1479-1483. [CrossRef]

36. Gordeev, S.; Gröschel, F.; Heinzel, V.; Hering, W.; Stieglitz, R. Numerical study of the flow conditioner for the IFMIF liquid lithium target. Fusion Eng. Des. 2014, 89, 1751-1757. [CrossRef]

37. Gordeev, S.; Gröschel, F.; Heinzel, V.; Hering, W.; Stieglitz, R. Numerical Analysis of Unsteady Flow Behavior in Flow Conditioner of IFMIF Liquid-Lithium Target. Fusion Sci. Technol. 2015, 68, 618-624. [CrossRef]

38. Gordeev, S.; Arena, P.; Bernardi, D.; Di Maio, P.A.; Nitti, F.S. Analytical and Numerical Assessment of Thermally Induced Pressure Waves in the IFMIF-DONES Liquid-Lithium Target. IEEE Trans. Plasma Sci. 2020, 48, 1485-1488. [CrossRef]

39. Tolli, J.E. Overview of Property Formulations for Helium, Nitrogen, Lithium, and Lithium-Lead in ATHENA/MOD1 with Comparison of Calculated Properties to Measured Properties, EGG-FSP-10245, Idaho National Engineering Laboratory, April 1992. Available online: https:/ / ui.adsabs.harvard.edu/abs/1992opfh.rept.....T/abstract (accessed on 30 September 2021).

40. Merrill, B.J. Modifications Made to the MELCOR Code for Analyzing Lithium Fires in Fusion Reactors, INEEL/EXT-2000-00489, April 2000. Available online: https:/ / www.osti.gov/biblio/764178-modifications-made-melcor-code-analyzing-lithium-firesfusion-reactors (accessed on 30 September 2021).

41. Jeppson, D.W.; Scoping, D.W. Studies: Behavior and control of lithium and lithium aerosols. HEDLTME 1982, 79-80. [CrossRef]

42. Jeppson, D.W. Results and Code Prediction Comparisons of Lithium-Air Reaction and Aerosol Behavior Tests; HEDL-TME 85-25; Hanford Engineering Development Laboratory: Richland, WA, USA, 1986; Available online: https://inis.iaea.org/search/ searchsinglerecord.aspx?recordsFor=SingleRecord\&RN=18000591 (accessed on 30 September 2021).

43. Merrill, B.; Humrickhouse, P.; Yoon, S.-J. Modifications to the MELCOR-TMAP code to simultaneously treat multiple fusion coolants. Fusion Eng. Des. 2018, 146, 289-292. [CrossRef]

44. Qiu, Y.; Arbeiter, F.; Fischer, U.; Tian, K. Neutronics analyses for the bio-shield and liners of the IFMIF-DONES test cell. Fusion Eng. Des. 2019, 146, 723-727. [CrossRef]

45. Frisoni, M.; Bernardi, D.; Nitti, F. Nuclear assessment of the IFMIF-DONES lithium target system. Fusion Eng. Des. 2020, 157, 111658. [CrossRef]

46. Marsh, D.J. A Thermal Shock Fatigue Study of Type 304 and 316 Stainless Steels; UKAEA Risley Nuclear Power Development Establishment (ND-R-606(S)): London, UK, 1982.

47. Bernard, L.J.; Lamain, G.L.; Verzeletti, G. Crack Initiation and Growth in Stainless Steel Tubes under Thermal Shocks; Radon, J.C., Ed.; Fracture and Fatigue: Pergamon, Turkey, 1980; pp. 391-400. ISBN 9780080261614. [CrossRef]

48. D'Onorio, M.; Giannetti, F.; Porfiri, M.T.; Caruso, G. Preliminary sensitivity analysis for an ex-vessel LOCA without plasma shutdown for the EU DEMO WCLL blanket concept. Fusion Eng. Des. 2020, 158, 111745. [CrossRef] 